\title{
Evidence for aggregation and export of cyanobacteria and nano-eukaryotes from the Sargasso Sea euphotic zone
}

\author{
M. W. Lomas ${ }^{1}$ and S. B. Moran ${ }^{2}$ \\ ${ }^{1}$ Bermuda Institute of Ocean Sciences, St. Georges, GE01, Bermuda \\ ${ }^{2}$ Graduate School of Oceanography, University of Rhode Island, Narragansett, RI 02882-1197, USA
}

Received: 9 September 2010 - Published in Biogeosciences Discuss.: 27 September 2010

Revised: 14 January 2011 - Accepted: 19 January 2011 - Published: 26 January 2011

\begin{abstract}
Pico-plankton and nano-plankton are generally thought to represent a negligible fraction of the total particulate organic carbon (POC) export flux in oligotrophic gyres due to their small size, slow individual sinking rates, and tight grazer control that leads to high rates of recycling in the euphotic zone. Based upon recent inverse modeling and network analysis however, it has been hypothesized that pico-plankton, including the cyanobacteria Synechococcus and Prochlorococcus, and nano-plankton contribute significantly to POC export, via formation and gravitational settling of aggregates and/or consumption of those aggregates by mesozooplankton, in proportion to their contribution to net primary production. This study presents total suspended particulate $(>0.7 \mu \mathrm{m})$ and particle size-fractionated $(10-20 \mu \mathrm{m}$, $20-53 \mu \mathrm{m},>53 \mu \mathrm{m})$ pigment concentrations from within and below the euphotic zone in the oligotrophic subtropical North Atlantic, collected using Niskin bottles and large volume in-situ pumps, respectively. Results show the indicator pigments for Synechococcus, Prochlorococcus and nano-eukaryotes are; (1) found at depths down to $500 \mathrm{~m}$, and; (2) essentially constant, relative to the sum of all indicator pigments, across particle size fractions ranging from $10 \mu \mathrm{m}$ to $>53 \mu \mathrm{m}$. Based upon the presence of chlorophyll precursor and degradation pigments, and that in situ pumps do not effectively sample fecal pellets, it is concluded that these pigments were redistributed to deeper waters on larger, more rapidly sinking aggregates likely by gravitational settling and/or convective mixing. Using available pigment and ancillary data from these cruises, these Synechococcus, Prochlorococcus and nano-plankton derived aggregates are estimated to contribute 2-13\% (5 $\pm 4 \%$ ), $1-20 \%$
\end{abstract}

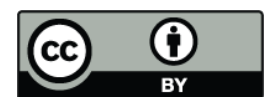

Correspondence to: $\mathrm{M}$. W. Lomas (michael.lomas@bios.edu)
$(5 \pm 7 \%)$, and $6-43 \%(23 \pm 14 \%)$ of the total sediment trap POC flux measured on the same cruises, respectively. Furthermore, nano-eukaryotes contribute equally to POC export and autotrophic biomass, while cyanobacteria contributions to POC export are one-tenth of their contribution to autotrophic biomass. These field observations provide direct evidence that pico- and nano-plankton represent a significant contribution to the total POC export via formation of aggregates in this oligotrophic ocean gyre. We suggest that aggregate formation and fate should be included in ecosystem models, particularly as oligotrophic regions are hypothesized to expand in areal extent with warming and increased stratification in the future.

\section{Introduction}

Traditionally, marine planktonic food web structure has been characterized by organism size (Michaels and Silver, 1988; Legendre and Lefevre, 1995), which has led to the identification of two distinct food web classifications; the herbivorous food web and the microbial loop. In the herbivorous food web, large phytoplankton such as diatoms dominate the primary producers, are consumed directly by mesozooplankton, and are in turn consumed by higher trophic levels (Steele and Frost, 1977). Ecosystems described by herbivorous food webs are generally highly productive, with correspondingly high particle organic carbon (POC) export fluxes, via aggregation and sinking of large diatoms and/or zooplankton fecal pellets (Eppley and Peterson, 1979). The microbial loop is characterized by small eukaryotic and prokaryotic phytoplankton that are consumed by microzooplankton grazers at rates similar to phytoplankton growth rates. Production of POC is largely recycled through dissolved organic matter and

Published by Copernicus Publications on behalf of the European Geosciences Union. 
bacteria (Pomeroy, 1974; Azam et al., 1983) with low POC export rates. In both food webs, producer/consumer relationships govern both the composition and the sedimentation rate of the sinking particles. In particular, recent work has revealed that interactions within and between the herbivorous and microbial food webs are more complex than originally proposed (Carlson et al., 1994; Dam et al., 1995; Rivkin et al., 1996; Steinberg et al., 2000; Serret et al., 2001; Lomas et al., 2002; Richardson and Jackson, 2007).

Pico- and nano-plankton have traditionally been thought to contribute little to POC export, due to their small size and tightly coupled micrograzer control (e.g., Michaels and Silver, 1988). There are several reports, however, of cyanobacteria and other pico-plankton being exported to the deep ocean via aggregates and salp fecal pellets. In particular, studies (e.g., Pfannkuche and Lochte, 1993; Urban et al., 1993) have documented the qualitative presence of cyanobacteria in the fecal pellets of crustacean and gelatinous zooplankton. Turley and Mackie (1995) and Waite et al. (2000) quantified cyanobacteria and pico-plankton POC export fluxes associated with organic aggregates although this was reported to be $<0.15 \%$ of the concurrently measured total POC export flux. Still other studies have quantified picoplankton and cyanobacteria indicator pigment concentrations in sediment trap material below $1000 \mathrm{~m}$ (Nodder and Gall, 1998; Thibault et al., 1999; Bianchi et al., 2002), with daily average sedimentation rates relative to euphotic zone standing stocks of $5 \pm 5 \%$. These published results imply a minor contribution of small cells to POC export compared to their standing stock biomass and presumably their net primary production. This assumes similar relative contributions to biomass and production which is often (e.g., Tremblay and Legendre, 1994; Maranon et al., 2000) but not always (Fernandez et al., 2003) observed. Moreover, these prior field studies have been conducted in nearshore or high productivity ocean regions; none have been conducted in the oligotrophic ocean gyres where cyanobacteria represent a larger $(>50 \%)$ fraction of the autotrophic biomass. In contrast, using an inverse model and network analysis of the oligotrophic equatorial Pacific and Arabian Sea, Richardson and Jackson (2007) concluded that the contribution of small phytoplankton (cyanobacteria and nano-plankton) to total POC export was in proportion to their net primary production in the euphotic zone with $\sim 10 \%$ exported indirectly via gravitational settling as aggregates (called POC in Table 1 of Richardson and Jackson, 2007) and the remainder exported directly as mesozooplankton fecal pellets arising from grazing on those aggregates. To date, however, there have been no direct field observations of cyanobacteria and nano-plankton export fluxes in oligotrophic regions to compare with those model results.

This study is one of several (Brew et al., 2009; Stewart et al., 2010) studying the relationship between phytoplankton community composition and POC export at the Bermuda Atlantic Time-series Study (BATS) site in the northwestern Sar- gasso Sea. We report an analysis of size-fractionated pigment concentrations within and below the euphotic zone from three cruises and confirm that aggregation and subsequent sedimentation (referred to as indirect export by Richardson and Jackson, 2007) is indeed an important mechanism by which cyanobacteria and nano-eukaryotes contribute to the total POC export flux in this oligotrophic gyre.

\section{Materials and methods}

\subsection{Study location}

The BATS site $\left(31^{\circ} 40^{\prime} \mathrm{N}, 64^{\circ} 10^{\prime} \mathrm{W}\right)$ is located $82 \mathrm{~km}$ southeast of Bermuda within the western North Atlantic Subtropical Gyre. Seasonality in primary productivity, plankton species composition, and POC export in this region are welldocumented (Michaels et al., 1994; DuRand et al., 2001; Lomas and Bates, 2004; Brix et al., 2006), but remains an active area of research as underlying mechanisms and relationships to a changing ocean are not understood. From January to April each year increased convective mixing leads to a deepening of the mixed layer and the injection of nutrient rich deep water to the euphotic zone (Fig. 1a). Subsequent water column re-stratification retains nutrients in the upperocean resulting in phytoplankton blooms and enhanced primary production (Fig. 1b), with POC export usually peaking several weeks to a month later. The remainder of the year is characterized by strong thermal stratification and reduced POC export rates. As a result of this seasonal cycle, the BATS site typically fluctuates between a summer-fall carbon retention system and a winter-spring carbon export system (Brix et al., 2006).

The principal phytoplankton taxa show clear seasonal succession patterns as well. The pico-plankton population is dominated by Prochlorococcus and Synechococcus, with Prochlorococcus reaching peak abundances during the summer/fall months while Synechococcus peaks during the winter/spring bloom period when primary production and POC export are highest (DuRand et al., 2001, Fig. 1c). The eukaryotic phytoplankton community is dominated by small pico- and nano-plankton (DuRand et al., 2001) particularly of the family Haptophyceae and Prasinophyceae, that also have a seasonal abundance maxima during the winter/spring period. Despite the large difference in numerical abundance, pico-/nano-eukaryotes, Prochlorococccus and Synechococcus, on average, each represent ca. one-third of autotrophic POC biomass (DuRand et al., 2001; Casey et al., 2011). Larger eukaryotic microphytoplankton such as diatoms and dinoflagellates are rare and generally comprise $<10 \%$ of total autotrophic carbon biomass (Priyadarshani and Lomas unpubl. data), but their abundance may increase during the intermittent passage of eddies (Sweeney et al., 2003; McGillicuddy et al., 2007) or after short-term storm events (Krause et al., 2009b; Lomas et al., 2009). 
Table 1. Summary of pigment concentrations $\left(\mathrm{ng} \mathrm{L}^{-1}\right)$ in each functional size group collected by in situ pump (Pump) or by 41 bottle from the CTD (Bottle). In this table $\mathrm{mPF}_{\text {conc }}$ is the sum of peridinin and fucoxanthin concentrations; $\mathrm{nPF}_{\text {conc }}$ is the sum of alloxanthin, 19-butanoyloxyfucoxanthin, and 19'-hexanoyloxyfucoxanthin concentrations; $\mathrm{pPF}_{\mathrm{conc}}$ is the sum of divinyl chlorophyll- $b$ and zeaxanthin concentrations, see methods for details and Hooker et al. (2005).

\begin{tabular}{|c|c|c|c|c|c|c|c|c|c|c|c|c|c|}
\hline \multirow[b]{2}{*}{$\begin{array}{l}\text { Cruise/ } \\
\text { Month }\end{array}$} & \multirow[b]{2}{*}{$\begin{array}{l}\text { Depth } \\
(\mathrm{m})\end{array}$} & \multicolumn{9}{|c|}{ Pump } & \multicolumn{3}{|c|}{ Bottle } \\
\hline & & \multicolumn{3}{|c|}{$\mathrm{pPF}_{\text {conc }}$} & \multicolumn{3}{|c|}{$n \mathrm{nF}_{\mathrm{conc}}$} & \multicolumn{2}{|c|}{$\mathrm{mPF}_{\text {conc }}$} & $>53$ & $\mathrm{pPF}_{\text {conc }}$ & $\mathrm{nPF}_{\text {conc }}$ & $\mathrm{mPF}_{\text {cono }}$ \\
\hline B217 & 5 & - & - & - & - & - & - & - & - & - & 105 & 40 & 9 \\
\hline \multirow[t]{13}{*}{ November } & 10 & - & - & - & - & - & - & - & - & - & 113 & 40 & 9 \\
\hline & 20 & - & - & - & - & - & - & - & - & - & 107 & 40 & 9 \\
\hline & 40 & - & - & - & - & - & - & - & - & - & 118 & 42 & 9 \\
\hline & 60 & - & - & - & - & - & - & - & - & - & 115 & 42 & 9 \\
\hline & 75 & 0.3 & 0.2 & 0 & 0.5 & 0.2 & 0.1 & 0.4 & 0.5 & 0 & - & - & - \\
\hline & 80 & - & - & - & - & - & - & - & - & - & 327 & 190 & 22 \\
\hline & 100 & - & - & - & - & - & - & - & - & - & 125 & 88 & 10 \\
\hline & 120 & - & - & - & - & - & - & - & - & - & 66 & 53 & 5 \\
\hline & 140 & - & - & - & - & - & - & - & - & - & 23 & 23 & 2 \\
\hline & 160 & - & - & - & - & - & - & - & - & - & 20 & 21 & 2 \\
\hline & 200 & 0 & 0 & 0.2 & 0.1 & 0.2 & 0.2 & 0.1 & 0.1 & 0.1 & 4 & 4 & 2 \\
\hline & 300 & 0.1 & 0.1 & 0.2 & 0.2 & .03 & 0.3 & 0 & 0.1 & 0.2 & - & - & - \\
\hline & 500 & 0.2 & 0.2 & 0.2 & 0.3 & 0.3 & 0.3 & 0.2 & 0.2 & 0.2 & - & - & - \\
\hline B219 & 5 & - & - & - & - & - & - & - & - & - & 280 & 111 & 15 \\
\hline \multirow[t]{14}{*}{ January } & 10 & - & - & - & - & - & - & - & - & - & 315 & 126 & 17 \\
\hline & 20 & - & - & - & - & - & - & - & - & - & 299 & 119 & 12 \\
\hline & 40 & - & - & - & - & - & - & - & - & - & 293 & 121 & 12 \\
\hline & 60 & - & - & - & - & - & - & - & - & - & 256 & 100 & 11 \\
\hline & 75 & 0.3 & 0.2 & 0 & 0.7 & 0.3 & 0.1 & 0.7 & 0.8 & 0.2 & - & - & - \\
\hline & 80 & - & - & - & - & - & - & - & - & - & 246 & 98 & 13 \\
\hline & 100 & - & - & - & - & - & - & - & - & - & 237 & 97 & 13 \\
\hline & 120 & - & - & - & - & - & - & - & - & - & 206 & 81 & 11 \\
\hline & 140 & - & - & - & - & - & - & - & - & - & 155 & 61 & 7 \\
\hline & 150 & 0.3 & 0.1 & 0 & 0.8 & 0.2 & 0.1 & 0.7 & 0.6 & 0.2 & - & - & - \\
\hline & 160 & - & - & - & - & - & - & - & - & - & 28 & 27 & 2 \\
\hline & 200 & 0 & 0 & 0.2 & 0.3 & 0.2 & 0.3 & 0 & 0.2 & 0.2 & 7 & 8 & 2 \\
\hline & 300 & 0.2 & 0.2 & 0.2 & 0.1 & 0.2 & 0.2 & 0.2 & 0.2 & 0.1 & - & - & - \\
\hline & 500 & 0.2 & 0.2 & 0.2 & 0.3 & 0.3 & 0.3 & 0.2 & 0.2 & 0.2 & - & - & - \\
\hline B221 & 5 & - & - & - & - & - & - & - & - & - & 234 & 81 & 6 \\
\hline \multirow[t]{13}{*}{ March } & 10 & - & - & - & - & - & - & - & - & - & 256 & 93 & 7 \\
\hline & 20 & - & - & - & - & - & - & - & - & - & 251 & 87 & 7 \\
\hline & 40 & - & - & - & - & - & - & - & - & - & 268 & 97 & 7 \\
\hline & 60 & - & - & - & - & - & - & - & - & - & 276 & 103 & 8 \\
\hline & 75 & 0.4 & 0.3 & 0.2 & 1.2 & 0.4 & 0.1 & 1 & 0.6 & 0.2 & - & - & - \\
\hline & 80 & - & - & - & - & - & - & - & - & - & 283 & 123 & 8 \\
\hline & 100 & - & - & - & - & - & - & - & - & - & 264 & 110 & 6 \\
\hline & 120 & - & - & - & - & - & - & - & - & - & 181 & 73 & 5 \\
\hline & 140 & - & - & - & - & - & - & - & - & - & 101 & 39 & 3 \\
\hline & 150 & 0.1 & 0.3 & 0.1 & 0.6 & 0.3 & 0.1 & 0.3 & 0.5 & 0.2 & - & - & - \\
\hline & 160 & - & - & - & - & - & - & - & - & - & 76 & 32 & 3 \\
\hline & 200 & 0.1 & 0.1 & 0.1 & 0.3 & 0.2 & 0.1 & 0.3 & 0.3 & 0.1 & 7 & 6 & 2 \\
\hline & 300 & 0 & 0 & 0.2 & 0.1 & 0.1 & 0.3 & 0.1 & 0.1 & 0.2 & - & - & - \\
\hline
\end{tabular}

a Pump samples were sequentially size-fractionated in situ into the following size ranges, 10-20 $\mu \mathrm{m}, 20-53 \mu \mathrm{m}$ and $>53 \mu \mathrm{m}$. Bottle samples were not size-fractionated. 

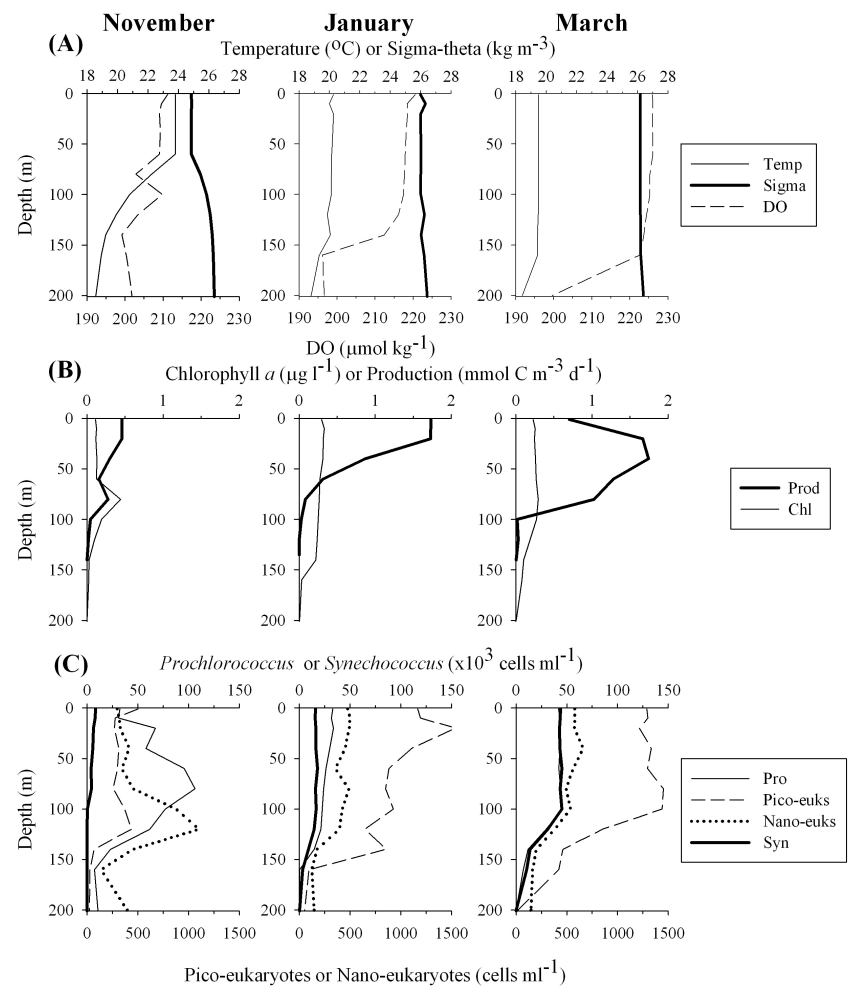

Fig. 1. Summary of hydrographic (A), chlorophyll and primary production (B) and pico- and nano-plankton (C) depth profiles for November (B217), January (B219) and March (B221) (left, middle and right panel within each row, respectively).

\subsection{Sample collection and at-sea processing}

Samples were collected on BATS cruises in November 2006, January 2007 and March 2007 (hereafter referred to by month). Samples were collected at 5-6 depths between 75-500 $\mathrm{m}$ using large-volume in-situ pumps (Challenger Oceanic Systems and Services, Surrey, UK, and McLane Laboratories, Falmouth, USA) for ${ }^{234} \mathrm{Th}$ and POC with samples for pigment analysis collected as a sub-sample punched out from the filter (see Brew et al., 2009 for more details). Seawater ( 200-1000 L, pigment sub-sample volume 48$128 \mathrm{~L}$, average $107 \mathrm{~L}$ ) was sequentially pumped through a series of three $142 \mathrm{~mm}$ diameter Nitex screens (for each depth; $10,20,53 \mu \mathrm{m})$. Unfortunately, due to the design of the pump head there is not a $1-10 \mu \mathrm{m}$ particulate size fraction that could be analyzed for pigment analysis. Sizefractionated particles collected on the Nitex screens were resuspended into GF/F filtered seawater via ultrasonication (Branson model \# 1210R-DTH, with Sonics set for $5 \mathrm{~min}$ and Degas set for $5 \mathrm{~min}$ ), vacuum-filtered onto pre-combusted $25 \mathrm{~mm}$ Whatman GF/F filters, and then frozen $\left(-80^{\circ} \mathrm{C}\right)$ in precombusted aluminum foil until analysis (see below).

Due to potential concerns that sonication of bulk samples for POC analysis might degrade pigments analyzed on sub- samples, a separate laboratory experiment was conducted using individual cultures of marine phytoplankton and a mixture of all cultures combined together. The phytoplankton cultures were split into duplicate samples, with one filtered immediately (Whatman GF/F) and frozen $\left(-80^{\circ} \mathrm{C}\right)$, and the other sonicated under the same conditions as field samples prior to filtration and storage. All samples were then processed as described in Sect. 2.3.

\subsection{HPLC pigment analyses}

Samples were analyzed following the procedures described in Van Heukelem and Thomas (2001). Briefly, samples were extracted in $90 \%$ acetone, kept on ice while sonicated (model 450, Branson Ultrasonics, Danbury CT, USA), and then clarified using a $0.45 \mu \mathrm{m}$ PFTE HPLC syringe cartridge fitted with glass fiber pre-filters (Scientific Resources Inc., Eatontown NJ, USA). Sub-samples $(900 \mu l)$ were analyzed on a Hewlett-Packard (HP, Waldbronn, Germany) series 1100 HPLC system. Pigment identities were determined based upon retention times of pure pigment standards and algal extracts of known pigment composition, and comparison of unknown pigment spectra to known standards. System response factors were determined from commercially obtained pigment standards where the concentrations were determined spectrophotometrically in the appropriate solvent using recommended extinction coefficients. Sample peak area was quantified using the response factor generated for each pure pigment standard.

From the pigment data, Proportion Factors (PF) for microplankton (mPF), nanoplankton (nPF) and picoplankton (which here includes the cyanobacteria and any picoplanktonic chlorophytes; pPF) were estimated as defined by Hooker et al. (2005; see their Table 5). These fractions are the quotient of absolute concentrations of specific indicator pigments and total indicator pigments (Table 1).

\subsection{Ancillary data}

BATS core data collected on these cruises are available from the Bermuda Institute of Ocean Sciences/Bermuda Atlantic Time-series Study web page (http://bats.bios.edu/). Specific details and information for all of the methods can be found on the web page as well under BATS Information/Methods, but a brief description of each method relevant to this particular work is given below.

Samples for pico-plankton enumeration by flow cytometry were collected from 9 depths between $0-140 \mathrm{~m}$, fixed with paraformaldehyde ( $0.5 \%$ final concentration), stored at $\sim 4{ }^{\circ} \mathrm{C}$ for $1-2 \mathrm{~h}$, before long term storage in liquid nitrogen. Samples were analyzed on a Becton Dickinson (formerly Cytopeia Inc.) Influx cytometer using a $488 \mathrm{~nm}$ blue excitation laser, appropriate chlorophyll- $a(692 \pm 20 \mathrm{~nm})$ and phycoerythrin $(580 \pm 15 \mathrm{~nm})$ bandpass filters, with daily calibration using $0.53 \mu \mathrm{m}$ and $2.88 \mu \mathrm{m}$ fluorescent microbeads 
(Spherotech Inc. Libertyville, Illinois, USA). Data files were analyzed from two-dimensional scatter plots based on red or orange fluorescence and characteristic light scattering properties (e.g., DuRand and Olson, 1996) using FCS Express 3.0 (DeNovo Software Inc. Los Angeles, California, USA). Prokaryotic pico-autotrophs were identified as either Synechococcus or Prochlorococcus based upon cell size and the presence or absence of phycoerythrin, respectively, and nano-eukaryotes as those chlorophyll containing cells larger than the $2.88 \mu \mathrm{m}$ calibration beads. Enumerated cells were converted to cell abundances by the volume-analyzed method (Sieracki et al., 1993). Precision of triplicate samples was $<5 \%$ for cell concentrations $>2000$ cells ml ${ }^{-1}$. Average cellular carbon content for each cell type was estimated from a log-log forward scatter/POC calibration specific for this instrument and analysis settings (e.g., DuRand et al., 2001; Casey et al., 2011).

POC sinking flux was quantified using surface-tethered particle interceptor traps (Knauer et al., 1979) deployed for $\sim 3$ days and filled with a brine solution $\left(50 \mathrm{~g} \mathrm{NaCl} \mathrm{L}^{-1}\right.$ above ambient seawater) containing formaldehyde $\left(0.7 \% \mathrm{v} \mathrm{v}^{-1}\right.$, final concentration). After manual removal of swimmers, samples were dried to constant weight at $65^{\circ} \mathrm{C}$, fumed overnight in a desiccator saturated with $\mathrm{HCl}$ fumes, re-dried at $65^{\circ} \mathrm{C}$, and then analyzed using a Control Equipment Model 440XA CHN elemental analyzer (Knap et al., 1997). Carbon fluxes were calculated from the mass of material captured in the trap, its surface area and deployment length.

\subsection{Statistical analyses}

All statistical analyses were conducted using Sigma-Stat version 3.5 (Systat Software). Data for each analysis were normally distributed so no data transformations were performed. ANOVA's were conducted and where appropriate followed by the student's t-test for all pairwise comparisons to determine which were significant.

\section{Results and discussion}

The seasonal change in hydrographic and biological parameters (Figs. 1,2) observed during this study is consistent with prior studies at BATS (e.g., Steinberg et al., 2001). One significant exception was the large bloom of Synechococcus in March 2007. Seasonally, Synechococcus abundances increased from $\sim 8000$ to $\sim 20000$ cells ml ${ }^{-1}$ (Fig. 2a), though abundances of $>40000$ cells ml $^{-1}$ in March represent one of the largest blooms of Synechococcus observed during the past 20 years of sampling at BATS (Lomas unpubl.). Nanoeukaryotes (Fig. 2b), such as haptophytes and prasinophytes, were also more abundant than typically observed.

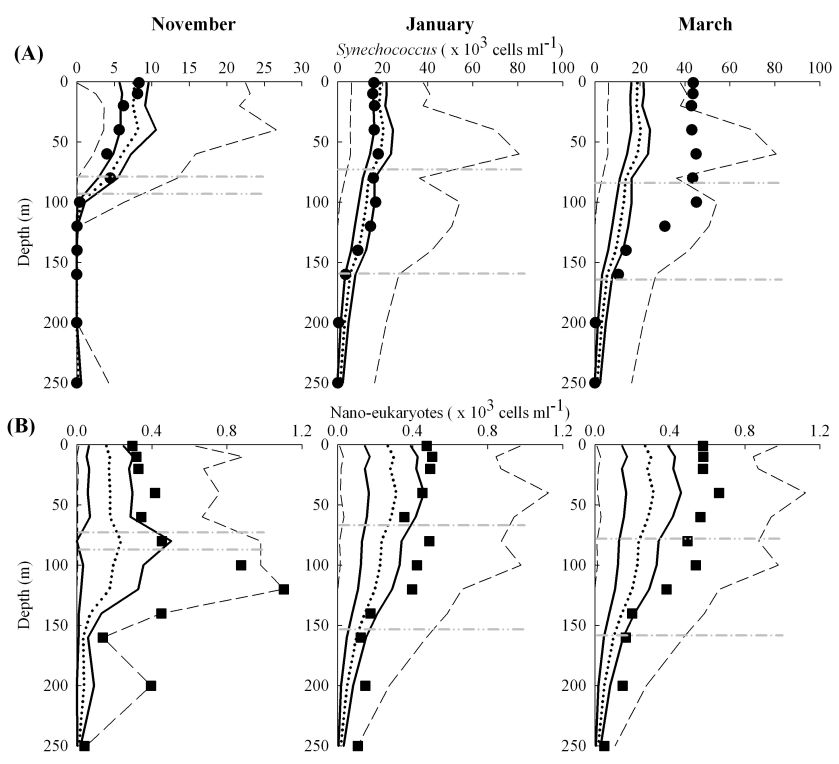

Fig. 2. Profiles of direct Synechococcus (A) and nano-eukaryote (B) counts by flow cytometry on cruises November (B217), January (B219) and March (B221). In each panel, counts for the specific cruise are shown by filled symbols, the average seasonal profile when each cruise occurred (e.g., B217 was in November so this is the average fall (September, October, and November) profile) is shown by the dotted line, \pm 1 std. dev. is shown by solid lines, and the minimum and maximum are shown by dashed lines. The horizontal lines in each panel represent the mixed layer depth on each cruise (dash-dot-dash) and 1\% PAR depth (dash-dot-dot-dash).

\subsection{Absolute and relative pigment distributions}

Seasonal changes in pigment concentrations within the euphotic zone (collected as part of the BATS core measurements using Niskin bottles) are consistent with the blooms of Synechococcus (zeaxanthin indicator pigment) and nanoeukaryotes (19'-hexanoyloxyfucoxanthin (19'-hex) indicator pigment) determined directly by flow cytometric cell abundance (Fig. 3). Pigment samples from the in situ pumps also indicate a seasonal increase in total chlorophyll- $a$ and these indicator pigments. There is a pronounced offset between pigment profiles, where depths overlap, on the same cruise collected using Niskin bottles and in situ pumps, with much lower concentrations determined in the pump samples than in the Niskin bottle samples. While pigment concentrations in the pump samples are very low (sub-nanomolar), there is analytical confidence in these results as the effective volume filtered for the sub-samples ranged from 49$128 \mathrm{~L}(107 \pm 22 \mathrm{~L})$. The most likely, but not the only (e.g., grazing on particles in the mesopelagic), explanation for the offset between the bottle and pump samples is that the 1$10 \mu \mathrm{m}$ size fraction was not sampled by in situ pump. This is supported by the observation that below $75 \mathrm{~m}$ the discrepancy between the bottle and pump pigment profiles, while 

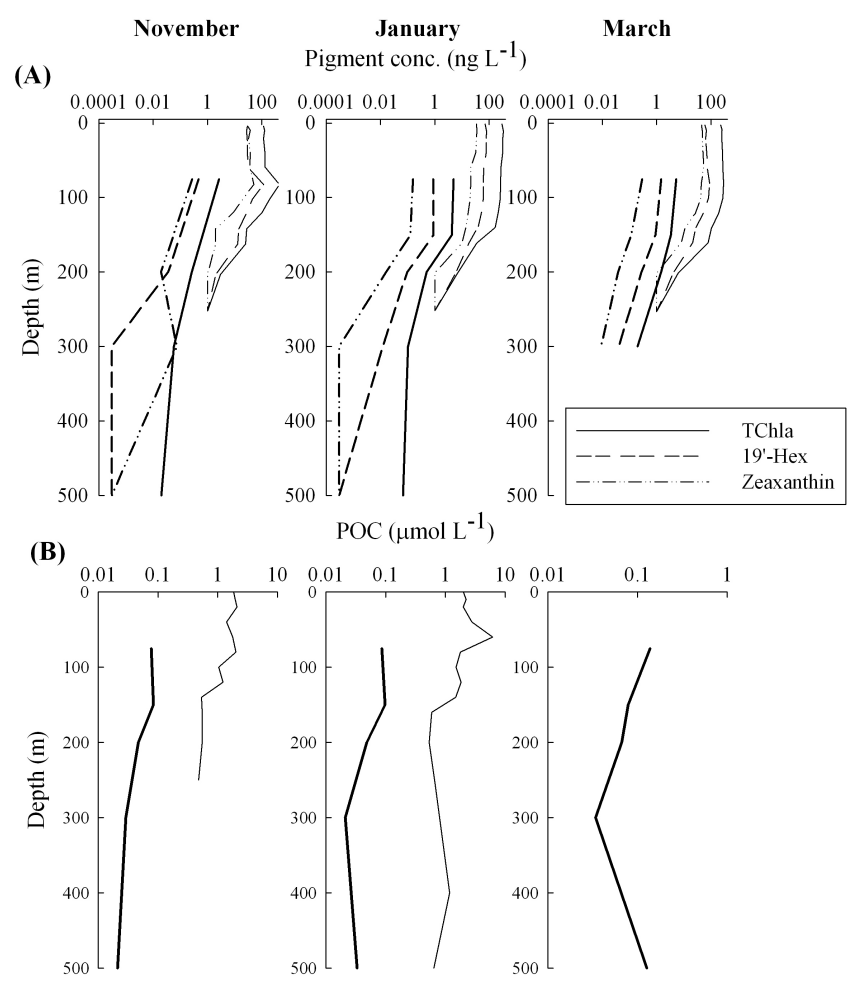

Fig. 3. Profiles of several key pigment $\left(\mathrm{ng} \mathrm{L}^{-1}\right.$; (A) and POC $\left(\mu \mathrm{mol} \mathrm{L}{ }^{-1}\right.$; (B) concentrations for November (B217), January (B219), and March (B221). Pigments are chlorophyll- $a$ (TChl- $a$, solid line), 19'-Hexanoyloxyfucoxanthin (19'-Hex, dashed line) indicative of haptophytes and zeaxanthin (dash-dot-dot line) indicative of cyanobacteria. Samples collected by Niskin bottles (thin lines) and in situ pumps (thick lines). POC data for Niskin bottles in March (B221) are missing due to instrument failure.

still present, is greatly reduced (ratio of Niskin:pump data for pigments shown in Fig. 3a is $>50$ at $75 \mathrm{~m}$ but $<10$ by $200 \mathrm{~m}$ ), which suggests a shift from single cells in the euphotic zone to a greater abundance of larger $(>10 \mu \mathrm{m}) \mathrm{ag}-$ gregates of cells at deeper depths. At shallower depths, the difference between $\mathrm{mPF}$ pigment concentrations in pumps and bottles was much smaller than the difference for $\mathrm{pPF}$ and nPF pigment concentrations (Fig. 2 and Table 1). The lower pigment concentrations in the pump samples were not an artifact of the sonication procedure because, regardless of the culture, pigment concentrations were not statistically different between the sonicated and non-sonicated cultures (student's t-test, $P>0.2$ in all pairwise comparisons; Fig. 4). The disruption of loosely aggregated particles upon impact with the filter during pumping cannot be ruled out, though at least one previous study suggests this is not a significant factor when comparing pigment data from Niskin and in situ pump profiles in the oligotrophic Mediterranean Sea (Liu et al., 2005). Similarly, the lower POC concentrations in pump samples compared to those from bottles is most likely due to the $1-10 \mu \mathrm{m}$ size fraction not being sampled using the pumps

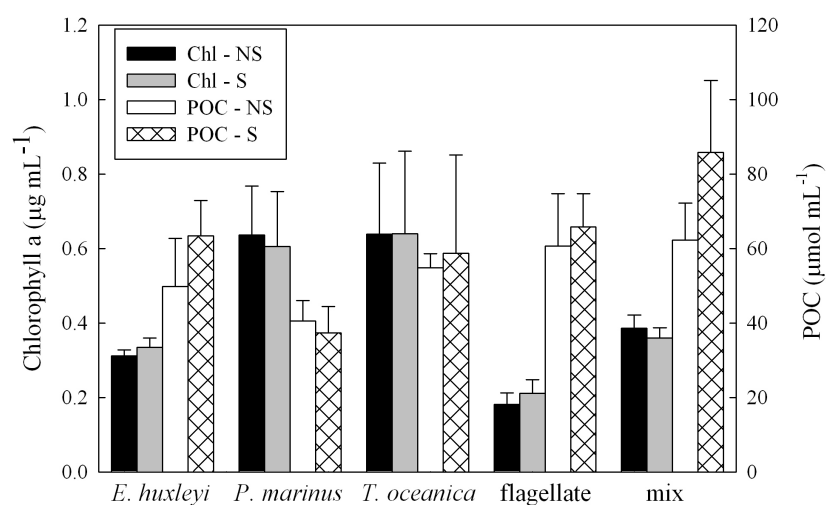

Fig. 4. Chlorophyll $\left(\mu \mathrm{g} \mathrm{mL}{ }^{-1}\right)$ and POC $\left(\mu \mathrm{mol} \mathrm{mL} L^{-1}\right)$ concentrations of paired samples, where one pair was sonicated (S designation in legend, see methods) and one was not (NS). Error bars are std. dev. and $\mathrm{N}=2$ in all cases.

(Fig. 4). Lower POC concentrations collected using pumps have also been attributed to higher Niskin filter blanks due to DOC adsorption to the filter (Moran et al., 1999) and avoidance of swimming zooplankton from in-situ pumps (Liu et al., 2005).

Partitioning of the absolute pigment concentrations into the three relative size classes, pico- (pPF), nano- (nPF) and micro-phytoplankton ( $\mathrm{mPF}$ ) in the euphotic zone, yields the typical result for the oligotrophic ocean: pPF and nPF dominate the euphotic zone autotrophic biomass, often in excess of $90 \%$, in the upper $150 \mathrm{~m}$ (Fig. 5), and mPF (i.e., larger diatoms and dinoflagellates) increases below the euphotic zone ( $\sim 100 \mathrm{~m}$, Siegel et al., 2001$)$. It is interesting that $\mathrm{mPF}$ decreased from $\sim 6 \%$ of phytoplankton pigment biomass in November (Fig. 5a) to $\sim 3 \%$ in March (Fig. 5c), which is inconsistent with the notion that diatoms increase in importance during spring blooms. However, in the Sargasso Sea diatom blooms typically respond to convective mixing within several days and can easily be missed in a monthly sampling regime such as at BATS (Krause et al., 2009b; Lomas et al., 2009). Also, due to differences in the vertical nutrient gradients, there is evidence for silica limitation in Sargasso Sea diatoms and a resulting long-term decline in their abundance (Brzezinski and Nelson, 1996; Krause et al., 2009a; Lomas et al., 2010).

Despite the difference in absolute pigment concentrations (Fig. 3), the relative pigment contributions are in reasonable agreement between the Niskin bottle and in situ pump data (cf. Figs. 5 and 6). The higher $75 \mathrm{~m} \mathrm{mPF}$ values for the in situ pump relative to bottle data may be due to the bottles undersampling large and rare diatoms that have been hypothesized to be important at the base of the euphotic zone in the Sargasso Sea (e.g., Goldman, 1993; Goldman and McGillicuddy, 2003). At $200 \mathrm{~m}$, mPF values for bottle samples were within a factor of 2 of the in situ pump $\mathrm{mPF}$ values on all cruises, ranging from $15-30 \%$ of the total 


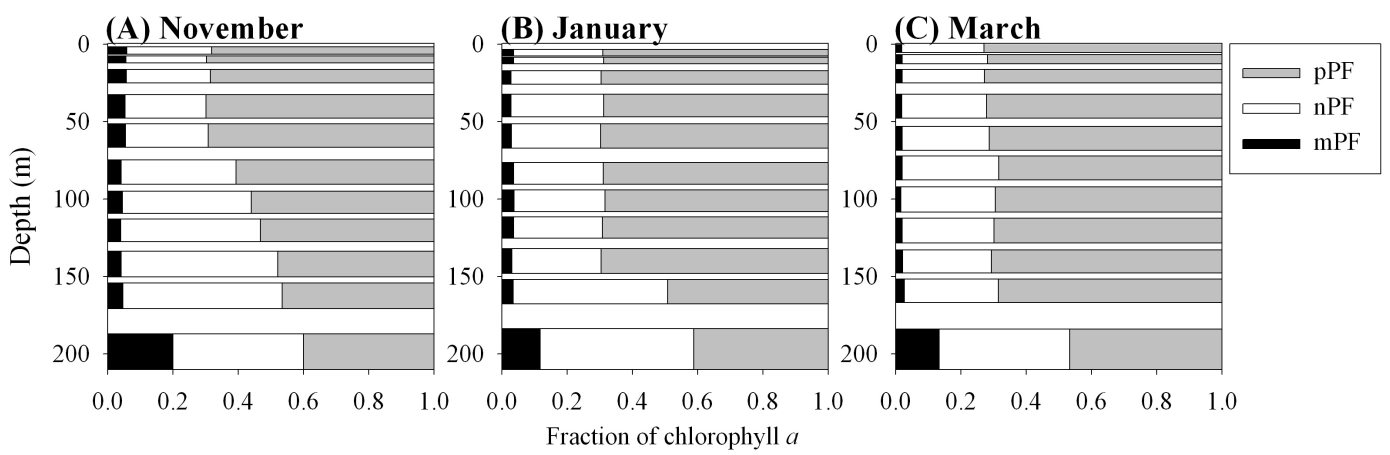

Fig. 5. Proportion of total pigments that are associated with each phytoplankton size group plotted as a function of sample collection depth and cruise; (A) November (B217), (B) January (B219), (C) March (B221). All data are Niskin bottle data.
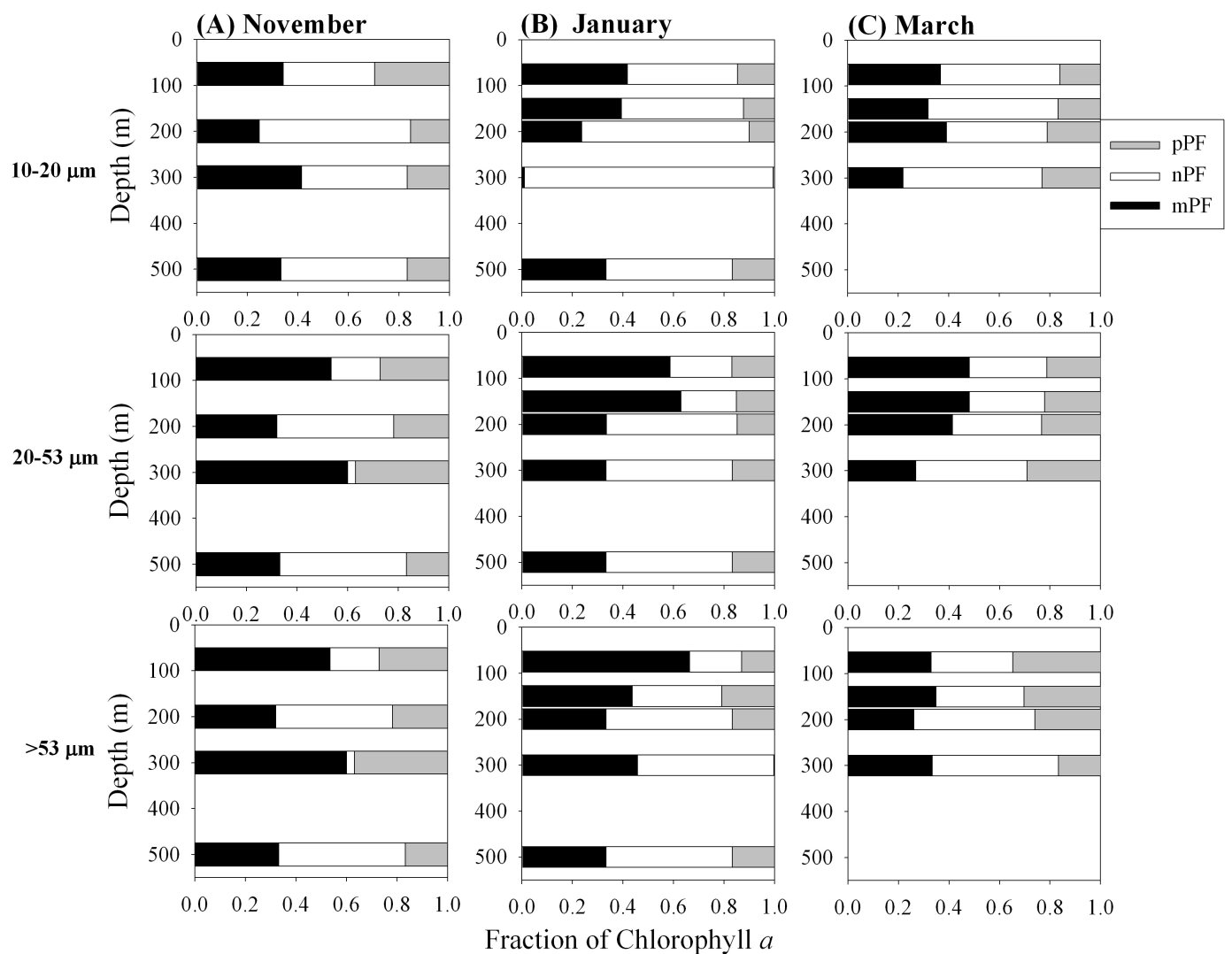

Fig. 6. Proportion of total pigments that are associated with each phytoplankton size group plotted as a function of sample depth and cruise (A) November (B217), (B) January (B219), (C) March (B221). Upper row of panels is data from particles retained on the 10-20 $\mu \mathrm{m}$ pump screen, middle row of panels is data from particles retained on the $20-53 \mu \mathrm{m}$ pump screen, bottom row of panels is data from particles retained on the $>53 \mu \mathrm{m}$ pump screen. All data are in situ pump data.

indicator pigments. The higher mPF (i.e., diatoms) below the euphotic zone is maintained through the deepest depths sampled and does not show a consistent trend with depth (Fig. 6). Interestingly, while reduced in magnitude relative to the euphotic zone, pigments associated with pico- and nanoplankton were as high as $70 \%$ of the total indictor pigments at depth (Fig. 6, Table 1). Similar to mPF, there was no systematic pattern in $\mathrm{pPF}$ and $\mathrm{nPF}$ pigments with depth, size fraction or season. These observations imply that pico- (including the cyanobacteria) and nano-plankton were exported to depth (e.g., Pfannkuche and Lochte, 1993; Urban et al., 1993; Nodder and Gall, 1998; Thibault et al., 1999; Waite et al., 2000). This export could be attributed to convective mixing and/or gravitational settling of aggregates to depth. Mixing in the Sargasso Sea, as in many ocean locations, is heterogenous in time and space. The mixed layer depths (using a density 
anomaly difference of $0.002 \mathrm{~kg} \mathrm{~m}^{-3}$ from the surface) during the November, January and March cruises sampled were $78 \pm 10 \mathrm{~m}(n=14), 129 \pm 50 \mathrm{~m}(n=11)$, and $133 \pm 53 \mathrm{~m}$ $(n=16)$, respectively. These measurements were made over the duration of a 7 day cruise and over a reasonably small spatial area $\left(\sim 100 \mathrm{~km}^{2}\right)$, and suggest that mixing might not account for the observed results as deep as $500 \mathrm{~m}$. Furthermore, the pigment profiles from the pumps are not uniform. This suggests that if mixing had happened prior to arrival on station, it was sufficiently early that aggregates mixed to depth had sunk to deeper depths and/or that shallow particles had grown back in to create the gradient. Gravitational settling of aggregates would result in a pigment concentration profile like what was observed. While the relative importance of convective mixing versus gravitational settling as a mechanism for getting aggregates to depth cannot be determined, aggregation appears to be an important process in facilitating the export of these small cells to depth.

\subsection{Evidence for aggregation of pico- and nano-plankton}

A statistically significant positive correlation between the euphotic zone integrated abundance of Synechococcus and pico-eukaryotes and POC export captured in surface tethered traps has recently been reported at BATS (Brew et al., 2009). This could be due to either seasonal co-variance of these variables and/or a mechanistic relationship by which these small cells contribute to POC export. There are several plausible mechanisms that have been proposed to account for the observations of Brew et al. (2009) and the suggested export of pPF and nPF to deeper waters reported in this study (Figs. 5, 6), including physical aggregation and settling, zooplankton grazing on aggregates and fecal pellet production, and/or interaction between free cells and settling aggregates/fecal pellets. With regard to fecal pellets, crustacean and gelatinous zooplankton are a typical source of sinking fecal pellets in food web models and produce fecal pellets that initially are larger than $53 \mu \mathrm{m}$ (e.g., Goldthwait and Steinberg, 2008; Eden et al., 2009). It is possible that fecal pellets may be fragmented into smaller particles by biological processes such as particle-attached microbial activity, zooplankton feeding, or zooplankton-induced shear (Steinberg et al., 2008). It seems unlikely, however, that fecal material from zooplankton would be collected uniformly on the smaller size fractions sampled by in situ pump, which would have to occur in order to explain the observed similar relative pigment distributions. Moreover, it is statistically unlikely that the in situ pumps would capture larger fecal pellets from the volumes filtered in this study ( 200-1000 L), suggesting that this pathway for material export was not adequately sampled in this study. Therefore, the observed export of these pigments to depth (Fig. 6 and Table 1) is proposed to occur by mechanisms other than zooplankton fecal pellets.

Microzooplankton are a source of smaller fecal pellets, however these are generally considered to have negligible sinking rates (Stoecker, 1984) and contribute little to fecal pellet fluxes in oligotrophic systems $(<1-2 \%$ of total pellet flux, Urrere and Knauer, 1981). Their importance may increase, however, where grazers feed directly on marine snow and other detritus (and pellets are deposited on the larger aggregate; Gowing and Silver, 1985). Regardless, the similar distributions of pigments across size classes would imply that all grazers had similar diets (i.e., no selective feeding, Schnetzer and Steinberg, 2002).

Grazing activity alters pigment composition due to degradation of the pigments within the gut of the grazer, in particular the chlorophylls, and occurs regardless of the type of grazer. The presence of phaeophorbide is indicative of chlorophyllous pigments that have been degraded during passage through a grazers gut (e.g., Madin and Cetta, 1984; Thibault et al., 1999). In particular, Bianchi et al. (2002) reported that chlorophyll:phaeopigment ratios in the water column with actively growing phytoplankton are $>10: 1$, whereas this ratio decreases to $1: 1$ or much less in particles comprised of fully degraded material. In the present study, there is a high correlation between chlorophyll- $a$ and phaeopigments in the bottle samples collected in the euphotic zone and the chlorophyll:phaeopigment ratio, $\sim 44$, is indicative of healthy cells (Fig. 7). Given the difference in pigment concentrations at the same depth between bottles and pumps, with bottles believed to have higher concentrations due to the presence of single cells, this seems reasonable. Pigments in the pump samples are also well correlated but the chlorophyll:phaeopigment ratio, 2.5, was lower than the bottle samples (dominated by healthy single cells) but not as low as that of fully degraded material (Fig. 7). This suggests that the aggregated material captured by the pumps, is likely a mixture of single cells attached to fecal material.

Recent work suggests that chlorophyllide is not a chlorophyll degradation intermediate as previously thought but rather a biosynthetic precursor to chlorophyll- $a$ (Schelberta et al., 2009). In this study, there is a tight coupling between chlorophyll- $a$ and chlorophyllide a regardless of collection method (Fig. 7) and an increase in this ratio from $\sim 8$ in the euphotic zone bottle samples (again dominated by single healthy cells) to $\sim 54$ in the deeper pump samples dominated by aggregated material. This change in the pigment ratio within each sample collection method is due to a roughly 10 -fold greater loss of chlorophyllide than chlorophyll, likely due to different stabilities of the molecules. If chlorophyllide is a precursor to chlorophyll and not a degradation product, this change is consistent with aggregations of scenescent cells, not fecal pellets, that are no longer actively synthesizing chlorophyll. These data support the hypothesis that aggregation and subsequent export by one of several mechanisms may be a significant pathway by which picoand nano-plankton plankton contribute to export production in low biomass environments such as the Sargasso Sea (e.g., Jackson et al., 2005). 


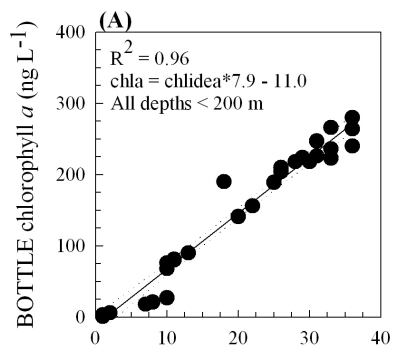

BOTTLE chlorophyllide $a\left(\mathrm{ng} \mathrm{L}^{-1}\right)$

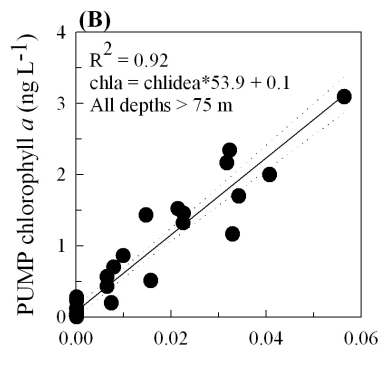

PUMP chlorophyllide $a\left(\mathrm{ng} \mathrm{L}^{-1}\right)$

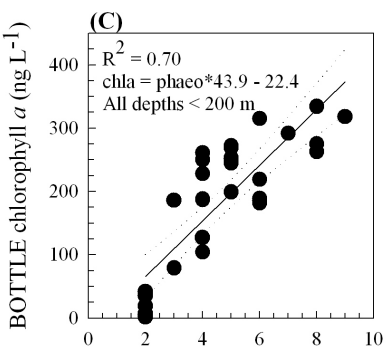

BOTTLE phaeopigments (ng L ${ }^{-1}$ )

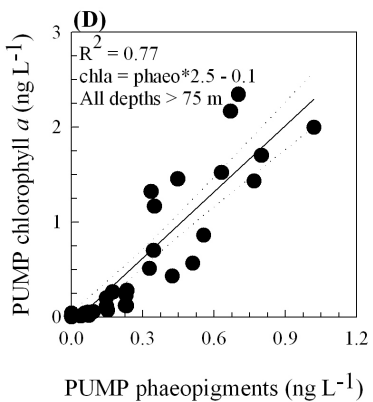

Fig. 7. Correlations between chlorophyll- $a$ and chlorophyllide a (A, B) and chlorophyll- $a$ and phaeophytin+phaeophorbide (collectively referred to as phaeopigments) (C, D) for euphotic zone samples collected by niskin bottle $(\mathbf{A}, \mathbf{C})$ and high volume in situ pump (B, D).

An important question is the relationship between particle size and settling speed; how large does a particle need to be before considered part of the export flux? The smallest particle fraction measured in this study, $10-20 \mu \mathrm{m}$, is smaller than the traditional size cutoff ( $>53 \mu \mathrm{m})$ used to define "sinking particles". This distinction of particles $>53 \mu \mathrm{m}$ being the sinking particles, however, is largely arbitrary. The observation that $\mathrm{pPF}$ and $\mathrm{nPF}$ are invariant with depth and size fraction (10-20 $\mu \mathrm{m}, 20-53 \mu \mathrm{m}$ and $>53 \mu \mathrm{m})$ suggests that the in situ pumps may have sampled a continuum of aggregating particles of similar origin and all $>10 \mu \mathrm{m}$, where smaller aggregates are continually colliding and sticking to each other to form larger aggregates with higher sinking speeds. In support of the suggestion that larger aggregrates are continually being formed from smaller aggregrates and subsequently sinking, Richardson and Jackson (2007) provide model results that suggest aggregates formed from cells as small as $1 \mu \mathrm{m}$ have settling speeds similar to those aggregrates formed from $30 \mu \mathrm{m}$ particles. Furthermore, nutrient limitation, a condition characteristic of oligotrophic gyres but not considered in Richardson and Jackson's model, would further increase the stickiness of particles and enhance the formation of aggregates from small particles (Klut and Stockner, 1991). Whether or not these smaller aggregates (e.g., 10-20 $\mu \mathrm{m}$ aggregates) are sinking at a rate high enough to be considered part of the sinking flux remains an open question, but clearly one with important biogeochemical implications.

\subsection{Contribution of Synechococcus, Prochlorococcus and nano-plankton derived aggregates to total POC export}

The contribution of Synechococcus, Prochlorococcus and nano-eukaryote derived aggregates to the total POC export flux, regardless of the mechanism (see discussion above), can be estimated using the ancillary data listed in Table 2 and data presented in Brew et al. (2009). This is a two step process; first, calculating a pigment flux rate, and; second, calculating the carbon associated with cells containing the specific indicator pigments. First, ${ }^{234} \mathrm{Th}$ and POC were measured on the same pump samples/size fractions as the pigments presented here, for the purposes of calculating the POC flux using the ${ }^{234}$ Th method (see Brew et al., 2009 for details on those methods and calculations). A very similar approach was used here, but rather than multiplying the euphotic zone ${ }^{234} \mathrm{Th}$ flux by the $\mathrm{POC} /{ }^{234} \mathrm{Th}$ ratio on large particles, the ${ }^{234} \mathrm{Th}$ flux was multiplied by the Indicator Pigment $/ 234 \mathrm{Th}$ ratio on large particles to estimate the pigment flux. Second, assuming that the difference in indicator pigment (listed next to group name in Table 2) concentrations between Niskin bottles and in situ pumps at 75, 150, and $200 \mathrm{~m}$ (depths where discrete flow cytometric enumeration of Synechococcus, Prochlorococcus and nano-eukaryotes are available) is entirely due to particles in the $1-10 \mu \mathrm{m}$ fraction not collected by pumps and that these particles are attributable to single cells of each group, the concentration of indicator pigment per individual cell can be calculated. Because these single cells are the source of aggregated and subsequently exported particles, the calculated indicator pigment per cell can be used together with the indicator pigment concentrations measured in the in situ pump samples (summed across all size fractions) to estimate the total number of aggregated cells for each taxonomic group in the collected sample. Using the calibration of POC per cell based upon forward light scatter (Methods), the concentration of POC per cell can be calculated for the each cell type. When combined with the estimated cell abundance, the total POC associated with each aggregate type can be calculated, using depth averaged POC:indicator pigment ratios. Water column average POC:Chl- $b$, POC:19'-hex, and POCZeax ratios were $2580 \pm 1700,1253 \pm 500$, and $6825 \pm 2460$ $\left(\mathrm{g} \mathrm{g}^{-1}\right)$, respectively, and did not vary significantly over the relatively short depth range considered here, likely due to high variance. The result of this two step calculation is an estimate of carbon flux via aggregates specific to each taxonomic group. Aggregate associated group-specific POC fluxes from pump samples were compared to the surface tethered sediment trap POC flux data at 150, 200 and $300 \mathrm{~m}$ for each cruise. Based on these calculations, aggregates contributed and estimated $2-13 \%$ ( $5 \pm 4 \%), 1-20 \%(5 \pm 7 \%)$, and $6-43 \%(23 \pm 14 \%)$ of the total POC export flux measured by sediment trap for Synechococcus, Prochlorococcus and nano-eukaryotes, respectively (Table 2). 


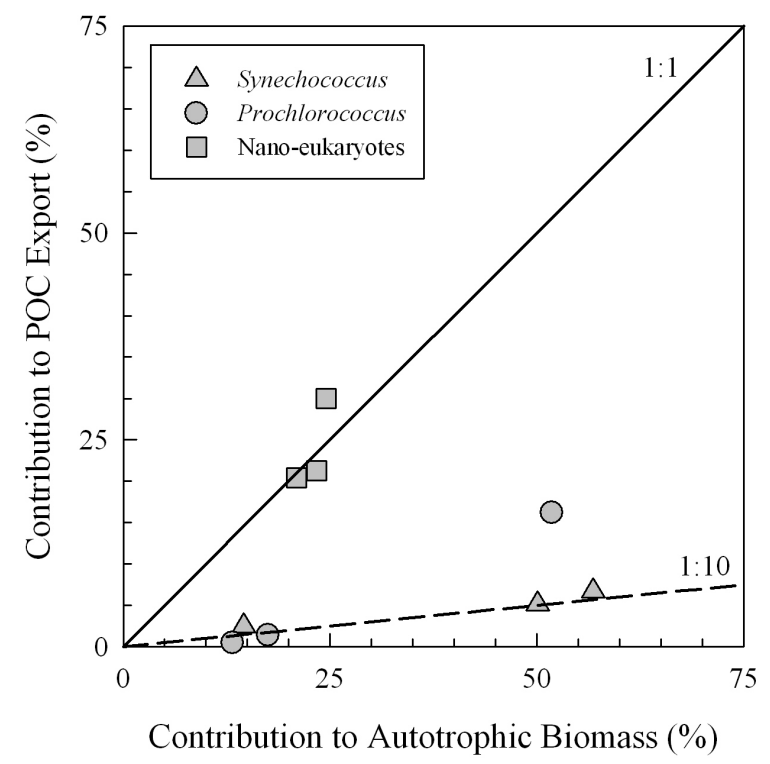

Fig. 8. Contribution of pico- and nano-plankton group export flux to total POC export fluxes (Table 2) plotted versus the contribution of each group to total autotrophic biomass. Groups are as defined in the legend and each month is a different data point. Solid line is the $1: 1$ ratio and dashed line is $1: 10$ ratio.

As a check on these calculations, POC:indicator pigment ratios $\left(\mathrm{g} \mathrm{g}^{-1}\right)$ from cultured Synechococcus, Prochlorococcus and haptophytes (representative of nano-eukaryotes as the indicator pigment 19'-hex was used in the calculations) were used to directly estimate the POC export flux of these organisms (Synechococcus, Liu et al., 1998; Six et al., 2004; Prochlorococcus, Moore et al., 1995; Bertilsson et al., 2003; nano-eukaryotes, Llewellyn and Gibb, 2000). Using the minimum (160:1, 120:1, 45:1 for Synechococcus, Prochlorococcus and nano-eukaryotes, respectively) and maximum (500:1, 230:1, 703:1) ratios found in the literature and the total indicator pigment concentrations from $150-300 \mathrm{~m}$, these groups represented $2-50 \%$ (7士12\%, Synechococcus), 1$37 \%$ (14 $\pm 12 \%$, Prochlorococcus), and 2-86\% (33 $\pm 33 \%$, nano-eukaryotes) of the total sediment trap POC export flux. These results are in reasonable agreement with results calculated from the direct field measurements described above.

Richardson and Jackson (2007) propose that pico- and nano-plankton contribute to POC export in direct proportion to their contribution to net primary production. The current study did not measure the contribution of pico- and nanoplankton groups to net primary production, only the contribution to total autotrophic POC biomass (Fig. 8). Datasets compiled for the Atlantic often (e.g., size-fractionation studies - Tremblay and Legendre, 1994; Maranon et al., 2000; flow cytometric sorting - Li, 1994; Jardillier et al., 2010) but not always (Fernandez et al., 2003) show a 1:1 correspondence between biomass and productivity for each size fraction or specific population. One explanation for the lack of correspondence is the selective loss of one group or size fraction during the incubation required to estimate primary production. In this study, however, only contributions to biomass are estimated, not production, and for the Atlantic Ocean the body of evidence suggests it would be a valid assumption. Plotting the contribution to total POC flux against the contribution to autotrophic POC biomass for each group, it is evident that nano-eukaryotes contribute equally to both parameters while the calculated POC export of cyanobacteria generally represents one-tenth of their contribution to biomass (Fig. 8). Although less than their contribution to total autotrophic biomass (and likely their contribution to net primary production), aggregation and gravitational settling of cyanobacteria alone is unlikely to account for the total export flux from the euphotic zone associated with this group because this group is known to be removed via fecal pellets. Richardson and Jackson (2007) suggest that indirect gravitational settling of aggregates accounts for $\sim 10 \%$ of the total export flux associated with these groups; a value similar to what is observed at BATS (Fig. 8). These results provide evidence based on direct field observations for aggregation as an important mechanism for the export of pico and nanoplankton derived POC. Moreover, these results demonstrate that cyanobacteria and nano-eukaryotes represent a quantitatively important contribution to the total POC export flux from the euphotic zone in the oligotrophic subtropical North Atlantic.

The results reported here are not inconsistent with the important role of larger eukaryotic diatoms and dinoflagellates in POC export. Pico- and nano-plankton together account for an average of $\sim 33 \%$ of the total POC flux. At BATS, diatoms have been estimated to account for $\sim 30 \%$ of the annual average total POC export and closer to $100 \%$ during bloom events (Nelson and Brzezinski, 1997), although these authors acknowledge that diatom blooms were not actually sampled. A more recent study, which did sample winter/spring diatom bloom conditions at BATS, reported that diatoms contributed a wide-range of $41-100 \%$ of the total POC flux (Krause et al., 2009b). While diatoms appear to be disproportionately important to total POC flux, pico- and nano-plankton make significant contributions to total POC export.

Results reported in this study support earlier observations at BATS of increasing winter/spring bloom POC export from the mid 1990's to the mid 2000's, during which time the euphotic zone phytoplankton community became increasingly dominated by Synechococcus (Brew et al., 2009; Lomas et al., 2010). Moreover, these data suggest that current ecosystem models (e.g., Bopp et al., 2005) should be restructured to allow for small phytoplankton to aggregate and contribute to POC export from the euphotic zone and specifically in the oligotrophic ocean - regions that are hypothesized to increase in areal extent with warming and increased stratification of the global ocean. 
Table 2. Contribution of group-specific aggregate carbon fluxes, estimated from pigment fluxes (using ${ }^{234} \mathrm{Th}$ method as described in text) and indicator pigment concentrations (given next to group name), to total sediment trap POC export at BATS. "Bottle-Pump" is the difference in indicator pigment concentrations between bottle and pump at given depths. For the " $75 \mathrm{~m}$ " depth, data from $80 \mathrm{~m}$ for the bottles was compared to data from $75 \mathrm{~m}$ for the pumps and for the " $150 \mathrm{~m}$ " depth, data from $160 \mathrm{~m}$ for the bottles was compared to data from $150 \mathrm{~m}$ for the pumps. Exp/POC is the ratio of group-specific POC export to total POC export. n.d. is not determined.

\begin{tabular}{|c|c|c|c|c|c|c|c|}
\hline $\begin{array}{l}\text { Cruise/ } \\
\text { Month }\end{array}$ & $\begin{array}{l}\text { Depth } \\
\text { (m) }\end{array}$ & $\begin{array}{l}\text { Bottle - Pump } \\
\quad\left(\mathrm{ng} \mathrm{L}^{-1}\right)\end{array}$ & $\begin{array}{c}\text { FCM } \\
\left(\times 10^{3} \text { cells L }^{-1}\right)\end{array}$ & $\begin{array}{c}\text { Cell flux* } \\
\text { (cells } \mathrm{m}^{-2} \mathrm{~d}^{-1} \text { ) }\end{array}$ & $\begin{array}{c}\text { Carbon flux } \\
\left(\mu \mathrm{mol} \mathrm{m} \mathrm{m}^{-2} \mathrm{~d}^{-1}\right)\end{array}$ & $\begin{array}{c}\text { POC Export } \\
\left(\mu \mathrm{mol} \mathrm{m} \mathrm{m}^{-2} \mathrm{~d}^{-1}\right)\end{array}$ & $\begin{array}{c}\text { Exp/POC } \\
(\%)\end{array}$ \\
\hline \multicolumn{8}{|c|}{ Synechococcus (zeaxanthin) } \\
\hline B217 & $" 75 "$ & 50.7 & 4465 & 23764 & - & - & - \\
\hline \multirow[t]{3}{*}{ November } & $" 150 "$ & n.d. & 9 & n.d. & n.d. & 1858 & n.d. \\
\hline & 200 & 1.0 & 10 & 204 & 42.0 & 1500 & 2.8 \\
\hline & 300 & - & - & 1463 & 2.3 & 2041 & 2.2 \\
\hline B219 & "75" & 20.8 & 15900 & 8000 & - & - & - \\
\hline \multirow[t]{3}{*}{ January } & “150” & 11.9 & 6213 & 66394 & 72.9 & 4067 & 1.8 \\
\hline & 200 & 1.0 & 404 & 9647 & 49.7 & 2542 & 4.8 \\
\hline & 300 & - & - & 657 & 13.5 & 1542 & 8.8 \\
\hline B221 & $" 75 "$ & 43.7 & 43501 & 241091 & - & - & - \\
\hline \multirow[t]{4}{*}{ March } & “150” & 9.4 & 12172 & 68729 & 211.1 & 8842 & 2.4 \\
\hline & 200 & 1.0 & 292 & 20882 & 40.7 & 5467 & 4.6 \\
\hline & 300 & - & - & 4020 & 22.6 & 2083 & 13.2 \\
\hline & & & & & & Mean \pm std dev & $5.1 \pm 4.0$ \\
\hline \multicolumn{8}{|c|}{ Prochlorococcus (divinyl Chlorophyll- $b$ ) } \\
\hline B217 & $" 75 "$ & 151.9 & 106404 & 70048 & - & - & - \\
\hline \multirow[t]{3}{*}{ November } & "150" & n.d. & 23020 & n.d. & n.d. & 1858 & n.d. \\
\hline & 200 & 9.7 & 10639 & 329041 & 187.1 & 1500 & 12.5 \\
\hline & 300 & - & - & 256485 & 219.6 & 2041 & 19.9 \\
\hline B219 & $" 75 "$ & 6.9 & 23939 & 146378 & - & - & - \\
\hline \multirow[t]{3}{*}{ January } & “150” & 8.7 & 14706 & 13486 & 28.5 & 4067 & 0.7 \\
\hline & 200 & 2.7 & 41 & 10147 & 2.8 & 2542 & 1.2 \\
\hline & 300 & - & - & 13554 & 5.6 & 1542 & 2.4 \\
\hline B221 & $" 75 "$ & 7.7 & 43965 & 39690 & - & - & - \\
\hline \multirow{4}{*}{ March } & “150” & 3.0 & 11728 & 0 & 6.5 & 8842 & 0.1 \\
\hline & 200 & 1.8 & 141 & 34442 & 3.7 & 5467 & 0.2 \\
\hline & 300 & - & - & 34955 & 15.0 & 2083 & 1.2 \\
\hline & & & & & & Mean \pm std dev & $4.8 \pm 7.4$ \\
\hline \multicolumn{8}{|c|}{ Nano-eukaryotes (19'-hexanoyloxyfucoxanthin) } \\
\hline B217 & “75” & 115.6 & 1866 & 6526 & - & - & - \\
\hline \multirow[t]{3}{*}{ November } & “150” & 13.9 & 117 & n.d. & n.d. & 1858 & n.d. \\
\hline & 200 & 1.7 & 31 & 5470 & 398.4 & 1500 & 26.6 \\
\hline & 300 & - & - & 5166 & 282.6 & 2041 & 33.4 \\
\hline B219 & $" 75 "$ & 60.2 & 446 & 5215 & - & - & - \\
\hline \multirow[t]{3}{*}{ January } & “150” & 38.2 & 143 & 5411 & 324.7 & 4067 & 8.0 \\
\hline & 200 & 5.8 & 140 & 1315 & 137.0 & 2542 & 18.2 \\
\hline & 300 & - & - & 1610 & 119.2 & 1542 & 37.7 \\
\hline B221 & $" 75 "$ & 87.5 & 494 & 9879 & - & - & - \\
\hline \multirow[t]{4}{*}{ March } & “150” & 26.1 & 200 & 8117 & 496.8 & 8842 & 5.6 \\
\hline & 200 & 3.7 & 148 & 3378 & 211.5 & 5467 & 13.0 \\
\hline & 300 & - & - & 1472 & 178.5 & 2083 & 42.6 \\
\hline & & & & & & Mean \pm std dev & $23.1 \pm 14.0$ \\
\hline
\end{tabular}

* estimation of the cell flux of each type in the aggregated material calculated from pigment per cell and pump pigment concentrations (see Table 1 for pump pigment data), and pigment fluxes as described in the text. ${ }^{* *}$ Estimation of group-specific carbon flux derived from cell flux and carbon cell ${ }^{-1}$. Synechococcus carbon cell ${ }^{-1}$ : 337, 314, $218 \mathrm{fgC} \mathrm{cell}^{-1}$ for November, January, March, respectively. Prochlorococcus carbon cell ${ }^{-1}$ : $90,57,52 \mathrm{fgC} \mathrm{cell}^{-1}$ for November, January, March, respectively. Nano-eukaryote carbon cell ${ }^{-1}$ : 6377 , $9779,8833 \mathrm{fgC} \mathrm{cell}^{-1}$ for November, January, March, respectively. Values are integrated between the neighboring depths. 
Acknowledgements. We thank the Captain and crew of the R/V Atlantic Explorer, Roger Kelly and Haley Brew for at-sea sampling assistance, and Amanda Burke for laboratory assistance, and the NSF for financial support (OCE-0327721 to SBM; OCE-0326685 to MWL and OCE-0927559 to MWL as a sub-award). We thank Susanne Neuer and Tammi Richardson for their comments on an earlier draft which improved the manuscript. This is Bermuda Institute of Ocean Sciences Contribution 2002.

Edited by: K. Suzuki

\section{References}

Azam, F., Fenchel, T., Field, J. G., Gray, J. S., Meyer-Reil, L. A., and Thingstad, F.: The ecological role of water column microbes in the sea, Mar. Ecol., 10, 257-263, 1983.

Bertilsson, S., Berglund, O., Karl, D. M., and Chisholm, S. W.: Elemental composition of marine Prochlorococcus and Synechococcus: implications for the ecological stoichiometry of the sea., Limnol. Oceanogr., 48, 1721-1731, 2003.

Bianchi, T. S., Rolff, C., Widbom, B., and Elmgren, R.: Phytoplankton pigments in Baltic Sea seston and sediments: Seasonal variability, fluxes, and transformations, Estuar. Coast. Shelf S., 55, 369-383, 2002.

Bopp, L., Aumont, O., Cadule, P., Alvain, S., and Gehlen, M.: Response of diatoms distribution to global warming and potential implications: A global model study, Geophys. Res. Lett., 32, L19606, doi:19610.11029/12005GL023653, 2005.

Brew, H. S., Moran, S. B., Lomas, M. W., and Burd, A. B.: Plankton community composition, organic carbon and thorium-234 particle size distributions, and particle export in the Sargasso Sea, J. Mar. Res., 67, 845-868, 2009.

Brix, H., Gruber, N., Karl, D., and Bates, N.: Interannual variability of the relationship between primary, net community and export production in the subtropical gyres, Deep-Sea Res. Pt. II, 53, 698-717, 2006.

Brzezinski, M. A. and Nelson, D. M.: Chronic substrate limitation of silicic acid uptake rates in the western Sargasso Sea, Deep-Sea Res., 43, 437-453, 1996.

Carlson, C., Ducklow, H., and Michaels, A.: Annual flux of dissolved organic carbon from the euphotic zone in the northwestern Sargasso Sea, Nature, 371, 405-408, 1994.

Dam, H. G., Roman, M. R., and Youngbluth, M. J.: Downward export of respiratory carbon and dissolved inorganic nitrogen by diel-migrant mesozooplankton at the JGOFS Bermuda TimeSeries Station, Deep-Sea Res. Pt. I, 42, 1187-1197, 1995.

DuRand, M. and Olson, R.: Contributions of phytopankton light scattering and cell concentration changes to diel variations in beam attenuation in the equatorial Pacific from flow-cytometric measurements of pico-, ultra-, and nanoplankton., Deep Sea Res. Pt. II, 43, 891-906, 1996.

DuRand, M., Olson, R., and Chisholm, S.: Phytoplankton population dynamics at the Bermuda Atlantic Time- series Study station in the Sargasso Sea, Deep-Sea Res. Pt. II, 48, 1983-2003, 2001.

Eden, B., Steinberg, D., Goldthwait, S. A., and McGillicuddy, D.: Zooplankton community structure in a cyclonic and mode-water eddy in the Sargasso Sea, Deep Sea Res. Pt. I, 56, 1757-1775, 2009.
Eppley, R. W. and Peterson, B. J.: Particulate organic matter flux and planktonic new production in the deep ocean, Nature, 282, 677-680, 1979.

Fernandez, E., Maranon, E., Moran, X. A. G., and Serret, P.: Potential causes for the unequal contribution of picophytoplankton to total biomass and productivity in oligotrophic waters, Mar. Ecol.Prog. Ser., 254, 101-109, 2003.

Goldman, J. and McGillicuddy, D.: Effect of large marine diatoms growing at low light on episodic new production, Limnol. Oceanogr., 48, 1176-1182, 2003.

Goldman, J. C.: Potential role of large oceanic diatoms in new primary production, Deep-Sea Res., 40, 159-168, 1993.

Goldthwait, S. A. and Steinberg, D.: Elevated biomass of mesozooplankton and enhanced fecal pellet flux in cyclonic and modewater eddies in the Sargasso Sea, Deep Sea Res. Pt. II, 55, 1360 1377, 2008.

Gowing, M. and Silver, M.: Minipellets: a new and abundant size class of marine fecal pellets, J. Mar. Res., 43, 395-418, 1985.

Hooker, S. B., Van Heukelem, L., Thomas, C., Claustre, H., J, Ras, J., Barlow, R., Sessions, H., Schluter, L., Perl, J., Trees, C., Stuart, V., Head, E. J. H., Clementson, L., Fishwick, J., Llewellyn, C. A., and Aiken, J.: The Second SeaWiFS HPLC Analysis Round-Robin Experiment (SeaHARRE-2), 124, 2005.

Jackson, G. A., Waite, A. M., and Boyd, P. W.: Role of algal aggregation in vertical carbon export during SOIREE and in other low biomass environments, Geophys. Res. Lett., 32, L13607, doi:13610.11029/12005GL023180, 2005.

Jardillier, L., Zubkov, M., Pearman, J., and Scanlan, D.: Significant $\mathrm{CO}_{2}$ fixation by small prymnesiophytes in the subtropical and tropical northeast Atlantic Ocean, ISME Journal, doi:10.1038/ismej.2010.1036, 2010.

Klut, M. and Stockner, J.: Picoplankton associations in an ultraoligotrophic lake on Vancouver Island, British Columnbia, Can. J. Fish. Aquat. Sci., 48, 1092-1099, 1991.

Knap, A., Michaels, A., Steinberg, D., Bahr, F., Bates, N., Bell, S., Countway, P., Close, A., Doyle, A., Howse, F., Gundersen, K., Johnson, R., Little, R., Orcutt, K., Parsons, R., Rathbun, C., Sanderson, M., and Stone, S.: BATS Methods Manual Version 4, U.S. JGOFS Planning Office, Woods Hole, 1997.

Knauer, G., Martin, J., and Bruland, K.: Fluxes of particulate carbon, nitrogen, and phosphorus in the upper water column of the northeast Pacific, Deep-Sea Res., 26, 97-108, 1979.

Krause, J., Lomas, M., and Nelson, D.: Biogenic silica at the Bermuda Atlantic Time-series Study site in the Sargasso Sea: Temporal changes and their inferred controls based on a 15-year record, Glob. Biogeochem. Cy., 23, GB3004, doi:3010.1029/2008GB003236, 2009a.

Krause, J., Nelson, D. M., and Lomas, M. W.: Biogeochemical responses to late-winter storms in the Sargasso Sea. II. Increased production and export of biogenic silica, Deep Sea Res. Pt. I, doi:10.1016/j.dsr.2009.1001.1002, 2009b.

Legendre, L. and Lefevre, J.: Microbial food webs and the export of biogenic carbon in oceans, Aquat. Microb. Ecol., 9, 69-77, 1995.

Li, W. K. W.: Primary Production of Prochlorophytes, Cyanobacteria, and Eukaryotic Ultraphytoplankton - Measurements from Flow Cytometric Sorting, Limnol. Oceanogr., 39, 169-175, 1994.

Liu, H., Campbell, L., Landry, M. R., Nolla, H. A., Brown, S. L., and Constantinou, J.: Prochlorococcus and Synechococcus 
growth rates and contributions to production in the Arabian Sea during the 1995 Southwest and Northeast Monsoons, Deep-Sea Res. Pt. II, 45, 2327-2352, 1998.

Liu, Z., Stewart, G., Cochran, J. K., Lee, C., Armstrong, R., Hirshberg, D., Gasser, B., and Miquel, J. C.: Why do POC concentrations measured using Niskin bottle collections sometimes differ from those using in-situ pumps, Deep Sea Res. Pt. I, 52, 1324-1344, 2005.

Llewellyn, C. A. and Gibb, S. W.: Intra-class variability in the carbon, pigment and biomineral content of prymnesiophytes and diatoms, Mar. Ecol. Prog.-Ser., 193, 33-44, 2000.

Lomas, M. W. and Bates, N. R.: Potential controls on interannual partitioning of organic carbon during the winter/spring phytoplankton bloom at the Bermuda Atlantic Time-series Study (BATS) site, Deep-Sea Res. Pt. I, 51, 1619-1636, 2004.

Lomas, M., Bates, N., Knap, A., Karl, D., Lukas, R., Landry, M., Bidigare, R., Steinberg, D., and Carlson, C.: Refining our understanding of ocean biogeochemistry and ecosystem functioning, EOS, 83, 559-561, 2002.

Lomas, M. W., Roberts, N. L., Lipschultz, F., Krause, J., Nelson, D. M., and Bates, N. R.: Biogeochemical responses to late-winter storms in the Sargasso Sea. IV. Rapid succession of major phytoplankton groups Deep Sea Res. Pt. I, 56, 892-908, 2009.

Lomas, M. W., Steinberg, D. K., Dickey, T., Carlson, C. A., Nelson, N. B., Condon, R. H., and Bates, N. R.: Increased ocean carbon export in the Sargasso Sea linked to climate variability is countered by its enhanced mesopelagic attenuation, Biogeosciences, 7, 57-70, doi:10.5194/bg-7-57-2010, 2010.

Madin, L. P. and Cetta, C.: The use of gut fluorescence to estimate grazing by oceanic salps, J. Plankton Res., 6, 475-492, 1984.

Maranon, E., Holligan, P. M., Varela, M., Mourino, B., and Bale, A. J.: Basin-scale variability of phytoplankton biomass, production and growth in the Atlantic Ocean, Deep Sea Res. Pt. I, 47, 825$857,2000$.

McGillicuddy, D. J., Anderson, L., Bates, N. R., Bibby, T., Buesseler, K. O., Carlson, C., Davis, C. S., Ewart, C., Falkowski, P. G., Goldthwait, S. A., Hansell, D., Jenkins, W. J., Johnson, R., Kosnyrev, V. K., Ledwell, J., Li, Q., Siegel, D., and Steinberg, D. K.: Eddy/Wind interactions stimulate extraordinary mid-ocean plankton blooms, Science, 316, 1021-1025, 2007.

Michaels, A. F. and Silver, M. W.: Primary production,sinking fluxes, and the microbial food web, Deep-Sea Res., 35, 473-490, 1988.

Michaels, A., Knap, A., Dow, R., Gundersen, J., Johnson, R., Sorensen, J., Close, A., Knauer, G., Lohrenz, S., Asper, V., Tuel, M., and Bidigare, R.: Seasonal patterns of ocean biogeochemistry at the U.S. JGOFS Bermuda Atlantic Time-series study site, Deep-Sea Res., 41, 1013-1038, 1994.

Moore, L. R., Goericke, R., and Chisholm, S. W.: Comparative Physiology of Synechococcus and Prochlorococcus - influence of light and temperature on growth, pigments, fluorescence and absorptive properties, Mar. Ecol.-Prog. Ser., 116, 259-275, 1995.

Moran, S., Charette, M., Pike, S., and Wicklund, C.: Differences in seawater particulate organic carbon concentration in samples collected using small- and large-volume methods: the importance of DOC adsorption to the filter blank, Mar. Chem., 67, 33-42, 1999.

Nelson, D. and Brzezinski, M.: Diatom growth and productivity in an oligotrophic midocean gyre: a 3-yr record from the Sargasso Sea near Bermuda, Limnol. Oceanogr., 43, 473-486, 1997.
Nodder, S. D. and Gall, M.: Pigment fluxes from the subtropical convergence region, east of New Zealand: relationships to planktonic community structure, N. Z. J. Mar. Freshw. Res., 32, 441465, 1998.

Pfannkuche, O. and Lochte, K.: Open ocean pelago-benthic coupling - cyanobacteria as tracers of sedimenting salp feces, DeepSea Res. Pt. I, 40, 727-737, 1993.

Pomeroy, L.: The ocean's food web, a changing paradigm, BioScience, 24, 499-504, 1974.

Richardson, T. and Jackson, G.: Small phytoplankton and carbon export from the surface ocean, Science, 315, 838-840, 2007.

Rivkin, R. B., Legendre, L., Deibel, D., Tremblay, J. E., Klein, B., Crocker, K. M., Roy, S., Silverberg, N., Lovejoy, C., Mesple, F., Romero, N., Anderson, M., Matthews, P., Savenkoff, C., and Grant Ingram, R.: Vertical flux of biogenic carbon in the ocean: Is there food web control? , Science, 272, 1163-1166, 1996.

Schelberta, S., Aubrya, S., Burla, B., Agnec, B., Kesslerc, F., Krupinskad, K., and Hörtensteinera, S.: Pheophytin pheophorbide hydrolase (pheophytinase) is involved in chlorophyll breakdown during leaf snescence in Arabidopsis, The Plant Cell, 21, 767-785, 2009.

Schnetzer, A. and Steinberg, D. K.: Natural diets of vertically migrating zooplankton in the Sargasso Sea, Mar. Biol., 141, 89-99, 2002.

Serret, P., Fernandez, R., Anadon, R., and Varela, M.: Trophic control of biogenic carbon export in Bransfield and Gerlache Straits, Antarctica, J. Plankton Res., 23, 1345-1360, 2001.

Siegel, D. A., Westberry, T. K., O’Brien, M. C., Nelson, N. B., Michaels, A. F., Morrison, J. R., Scott, A., Caporelli, E. A., Sorensen, J. C., Maritorena, S., Garver, S. A., Brody, E. A., Ubante, J., and Hammer, M. A.: Bio-optical modeling of primary production on regional scales: the Bermuda BioOptics project, Deep-Sea Res. Pt. II, 48, 1865-1896, 2001.

Sieracki, M., Verity, P., and Stoecker, D.: Plankton community response to sequential silicate and nitrate depletion during the 1989 North Atlantic spring bloom, Deep Sea Res. Pt. II, 40, 213-226, 1993.

Six, C., Thomas, J., Brahamsha, B., Lemoine, Y., and Partensky, F.: Photophysiology of the marine cyanobacterium Synechococcus sp. WH8102, a new model organism, Aquat. Microb. Ecol., 35, 17-29, 2004.

Steele, J. and Frost, B.: The structure of plankton communities, Philos. Trans. R. Soc. Lond. Ser. B-Biol. Sci., 280, 485-534, 1977.

Steinberg, D. K., Carlson, C. A., Bates, N. R., Goldthwait, S. A., Madin, L. P., and Michaels, A. F.: Zooplankton vertical migration and the active transport of dissolved organic and inorganic carbon in the Sargasso Sea, Deep-Sea Res. Pt. I, 47, 137-158, 2000 .

Steinberg, D. K., Carlson, C. A., Bates, N. R., Johnson, R. J., Michaels, A. F., and Knap, A. H.: Overview of the US JGOFS Bermuda Atlantic Time-series Study (BATS): a decade-scale look at ocean biology and biogeochemistry, Deep-Sea Res. Pt. II, 48, 1405-1447, 2001.

Steinberg, D., Van Mooy, B. A. S., Buesseler, K. O., Boyd, P., Kobari, T., and Karl, D.: Bacterial vs. zooplankton control of sinking particle flux in the ocean's twilight zone, Limnol. Oceanogr., 53, 1327-1338, 2008. 
Stewart, G., Moran, S. B., and Lomas, M. W.: Seasonal POC fluxes at BATS estimated from ${ }^{210}$ Po deficits, Deep Sea Res. Pt. I, 57, 113-124, 2010.

Stoecker, D. K.: Particle production by plankton ciliates, Limnol. Oceanogr., 29, 930-940, 1984.

Sweeney, E., McGillicuddy, D., and Buesseler, K.: Biogeochemical impacts due to mesoscale eddy activity in the Sargasso Sea as measured at the Bermuda Atlantic Time-series Study (BATS), Deep-Sea Res. Pt. II, 50, 3017-3039, 2003.

Thibault, D., Roy, S., Wong, C. S., and Bishop, J. K. B.: The downward flux of biogenic material in the NE subarctic Pacific: importance of algal sinking and mesozooplankton herbivory, Deep Sea Res. Pt. II, 46, 2669-2697, 1999.

Tremblay, J. and Legendre, L.: A model for the size fractionated biomass and production of marine phytoplankton, Limnol. Oceanogr., 39, 2004-2014, 1994.
Turley, C. M. and Mackie, P. J.: Bacterial and cyanobacterial flux to the deep NE Atlantic on sedimenting particles, Deep-Sea Res. Pt. I, 42, 1453-1474, 1995.

Urban, J. L., McKenzie, C. H., and Deibel, D.: Nanoplankton found in fecal pellets of macrozooplankton in coastal Newfoundland waters, Bot. Marina, 36, 267-281, 1993.

Urrere, M. and Knauer, G. A.: Zooplankton fecal pellet fluxes and vertical transport of particulate organic material in the pelagic environment, J. Plankton Res., 3, 369-387, 1981.

Van Heukelem, L. and Thomas, C.: Computer-assisted highperformance liquid chromatography method development with applications to the isolation and analysis of phytoplankton pigments, J. Chromatogr., 910, 31-49, 2001.

Waite, A. M., Safi, K., Hall, J., and Nodder, S. D.: Mass sedimentation of picoplankton embedded in organic aggregates, Limnol. Oceanogr., 45, 87-97, 2000. 